Вісник Дніпропетровського університету. Біологія. Екологія. -2009. - Вип. 17, т. 1. - С. 65-69. Visnyk of Dnipropetrovsk University. Biology. Ecology. - 2009. - Vol. 17, N 1. - P. 65-69.

УДК 612.017.34:616.348-002

С. Ю. Сгорова, В. Є. Кудрявцева

Інститут гастроентерології АМН України, Дніпропетровськ

\title{
РОЛЬ ІМУННИХ ПОРУШЕНЬ У ХВОРИХ НА НЕСПЕЦИФІЧНИЙ ВИРАЗКОВИЙ КОЛІТ
}

Проведено імунологічне обстеження 45 хворих на неспецифічний виразковий коліт. Надано загальну характеристику змін імунологічних параметрів. Установлено дисбаланс у клітинній ланці імунітету, активацію гуморальної ланки та підвищення рівня прозапальних цитокінів у хворих на неспецифічний виразковий коліт. Визначено рейтинговий алгоритм імунних порушень у обстежених хворих.

\author{
S. U. Yegorova, V. Y. Kudryavceva
}

Institute of Gastroenterology of Academy of Medical Sciences of Ukraine, Dnipropetrovsk

\section{IMMUNE SYSTEM DISORDER IN PATIENTS WITH ULCERATIVE COLITIS}

The immunological examination of 45 patients with ulcerative colitis has been carried out. The general characteristics of changes of the immunological parameters have been given. We found the disorders of cellular immunity, activation of humoral immunity, increase of concentration pro-inflammatory cytokines in patients with ulcerative colitis. The immune disorders algorithm was characterised for studied patients.

\section{Ветуп}

Неспецифічний виразковий коліт - хронічне захворювання товстої кишки нез'ясованої етіології, що характеризується дифузним запальним ураженням іiї слизової оболонки, утворенням виразок і, нерідко, кишкових кровотеч [1]. Дана патологія одна з найвагоміших проблем сучасної гастроентерології. Це обумовлено поширеністю хвороби в усьому світі, тенденцією до збільшення кількості випадків захворювань як серед дорослого населення, так і серед дітей, важкістю та різноманітністю клінічних проявів, ускладнень, які нерідко потребують хірургічного втручання, а також високою летальністю [2]. Невідома етіологія, відсутність чітких уявлень про патогенез обумовлюють труднощі терапії цих захворювань [11]. Морфологічні зміни слизової оболонки кишки хворих виразковим колітом характеризуються запальною інфільтрацією, що складається із плазматичних клітин, лімфоцитів, гістіоцитів, нейтрофільних гранулоцитів [8]. Згідно з імунною концепцією розвитку виразкового коліту патогенетичний каскад запалення починається з проникнення в кишечник антигену (інфекційний агент або харчовий компонент). Унаслідок активації $T$-лімфоцитів синтезуються медіатори запалення та здійснюється подальша активація імунокомпетентних клітин, що призводить до виникнення запального процесу у слизовій оболонці кишки [12].

Під впливом генетичної схильності та руйнівних факторів зовнішнього середовища набуває розвитку імунологічний дисбаланс, продукуються медіатори запалення (цитокіни), відбувається деструкція слизової оболонки кишечника [3]. Міграція в місце 
пошкодження мононуклеарних клітин і нейтрофілів із судинного русла збільшує запальну інфільтрацію слизової оболонки та призводить до звільнення нових порцій медіаторів запалення [10].

Для прогресування запально-деструктивного процесу у слизовій оболонці шлунково-кишкового тракту має значення незбалансована продукція фагоцитами цитокінів [6; 13]. Ці біологічно активні сполуки не тільки впливають на імунні реакції, а і втручаються в метаболічні процеси. Підвищення їх синтезу свідчить про активність патологічного процесу, а дефіцит - про пригнічення неспецифічного захисту, що також негативно впливає на перебіг основного захворювання [5; 7].

При поєднанні імуноглобулінів з антигеном утворюються циркулюючі імунні комплекси (ЦІК) як компонент нормальної імунної відповіді, із нейтралізацією чи елімінацією антигену. Але за певних умов вони можуть фіксуватись у судинах і викликати загальну запальну реакцію. Їх підвищений рівень свідчить про активність патологічного процесу, порушення системи комплементу, фагоцитозу тощо [4; 14].

Таким чином, вивчення характеру імунологічних розладів, їх ступеня, визначення кореляції між імунологічними показниками у хворих на неспецифічний виразковий коліт має велике значення для розробки нових методів лікування та профілактики виразкового коліту. Тому мета даної роботи - охарактеризувати імунний статус хворих на неспецифічний виразковий коліт.

\section{Матеріал і методи досліджень}

Обстежено 45 хворих на неспецифічний виразковий коліт. Контрольну групу склала 41 здорова особа. Імунний статус хворих оцінювали за допомогою комплексу стандартних уніфікованих методів, які дозволяють судити про кількісний та функціональний стан клітинного та гуморального імунітету. Мононуклеарні клітини виділяли із гепаринізованої периферичної венозної крові пацієнтів у градієнті щільності фіколуверографіну 1,077 г/мл. Субпопуляційний склад лімфоцитів визначали методом непрямої імунофлюоресценції за допомогою моноклональних антитіл (фірми Сорбент ТМ, Москва) до кластерів: CD3+ (T-лімфоцити), CD19+ (B-лімфоцити), CD4+ (T-хелпери), $\mathrm{CD} 8+$ (T-цитотоксичні лімфоцити), $\mathrm{CD} 16+$ (натуральні кілери), $\mathrm{CD} 25+$ (рецептори до IL-2), CD95+ (FAS/APO-1), HLA-DR+. Вміст імуноглобулінів $A, M, G$ у сироватці крові визначали імуноферментним методом за допомогою тест-систем ТОВ НВЛ Гранум (Харків). Інтерлейкін 8 (ІЛ-8), фактор некрозу пухлин-альфа (ФНП- $\alpha$ ), інтерферональфа (ІФН- $\alpha$ ), інтерферон-гама (ІФН- $\gamma$ ) визначали в сироватці крові методом імуноферментного аналізу за допомогою тест-систем ЗАО Вектор-Бест (Новосибірськ). Вимірювання оптичної щільності проводили за допомогою імуноферментного аналізатоpa Stat Fax 303 Plus (США). Циркулюючі імунні комплекси визначали методом селективної преципітації з розчином поліетиленгліколю-6000 [15]. Для оцінки імунного статусу використовували комплексний підхід, який базувався на частотному аналізі та визначенні коефіцієнта діагностичної цінності для кожного показника [9]. Ступінь розладів імунної системи розраховували як співвідношення показника конкретного хворого до показника, прийнятого за норму, виражене у відсотках. Величина від 1 до 33 \% відповідає першому ступеню імунних розладів, цей стан $\epsilon$ транзиторним і не потребує імунокорегувальної терапії, від 34 до 66 \% - відповідає другому ступеню, понад $66 \%$ третьому ступеню. Далі, враховуючи ступінь розладів імунної системи та величину коефіцієнта діагностичної цінності для кожного показника, параметри імунної системи розміщували у порядку зменшення їх значимості, вказуючи вектор цих змін (супресія або стимуляція). Таким чином установили рейтинговий алгоритм розладів імунної сис- 
теми обстежених хворих. Отримані результати обробляли статистично з використанням $t$-критерію Стьюдента. Відмінності двох показників вважались достовірними при $p<0,05$.

\section{Результати та їх обговорення}

У хворих на неспецифічний виразковий коліт встановлено достовірне $(p<0,05)$ зниження загальної кількості $T$-лімфоцитів (у 54,6 \% хворих визначено імунну недостатність другого ступеня) (табл. 1). Поряд із цим, у самій популяції $T$-клітин хворих спостерігали певний дисбаланс. Кількість $T$-хелперів достовірно нижча норми у 53,9 \% хворих (імунна недостатність другого ступеня). Натомість, кількість супресорів у хворих перевищує норму: відхилення другого ступеня у 26,9 \% хворих, третього ступеня у 7,7 \% хворих. Ми спостерігали достовірне зниження індексу імунорегуляції у обстежених хворих, що викликає стійкі порушення в імунній системі та хронізацію патологічного процесу. Кількість $N K$-клітин із фенотипом CD16+ мала тенденцію до підвищення. Про активацію гуморальної ланки імунітету свідчило збільшення вмісту клітин із фенотипом CD19+, підвищений рівень ЦІК та збільшення концентрації сироваткових імуноглобулінів. Збілышення кількості $B$-лімфоцитів відповідало другому ступеню у 19,2 \% хворих, третьому ступеню - у 23,1%. Співвідношення $T / B$ лімфоцитів було достовірно зниженим. У хворих на виразковий коліт спостерігали підвищення рівня $\operatorname{Ig} A$ та $\operatorname{Ig} M$.

Найзначніші відхилення від норми спостерігали для $\operatorname{Ig} M-$ у 20,0 \% - третього ступеня, у 10,0 \% - другого ступеня. Достовірне підвищення концентрації ЦІК спостерігали у $66,7 \%$ хворих третього ступеня, та у $20,0 \%$ хворих - другого ступеня.

Таблиия 1

Показники клітинного та гуморального імунітету хворих на неспецифічний виразковий коліт

\begin{tabular}{|c|c|c|}
\hline Показник & Хворі $(n=45)$ & Контроль $(n=41)$ \\
\hline Лейкоцити, $10^{9} /$ л & $5,05 \pm 0,27$ & $5,35 \pm 0,21$ \\
\hline Лімфоцити, \% & $26,19 \pm 1,57$ & $28,71 \pm 0,81$ \\
\hline Лімфоцити, $10^{9} /$ л & $1,32 \pm 0,11 *$ & $1,61 \pm 0,07$ \\
\hline$T$-лімфоцити (CD3+), \% & $37,15 \pm 1,06^{*}$ & $50,88 \pm 0,68$ \\
\hline$T$-лімфоцити (CD3+), $10^{9} /$ л & $0,48 \pm 0,03 *$ & $0,76 \pm 0,04$ \\
\hline$T$-хелпери (CD4+), \% & $26,15 \pm 1,22 *$ & $38,71 \pm 0,52$ \\
\hline$T$-хелпери(CD4+), $10^{9} /$ л & $0,35 \pm 0,03 *$ & $0,53 \pm 0,03$ \\
\hline T-супресори (CD8+), \% & $22,33 \pm 1,34 *$ & $18,39 \pm 0,57$ \\
\hline$T$-супресори (CD8+), 10\% /л & $0,29 \pm 0,03$ & $0,30 \pm 0,02$ \\
\hline$N K$-кліт. (CD16+), \% & $21,52 \pm 1,65$ & $19,07 \pm 0,9$ \\
\hline$N K$-кліт. (CD16+), $10^{9} /$ л & $0,31 \pm 0,04$ & $0,31 \pm 0,02$ \\
\hline$B$-лімфоцити (CD19+), \% & $21,74 \pm 1,58^{*}$ & $14,78 \pm 0,48$ \\
\hline$B$-лімфоцити (CD19+), $10^{9} /$ л & $0,32 \pm 0,04$ & $0,25 \pm 0,01$ \\
\hline$T / B$-лімфоцити & $1,89 \pm 0,15^{*}$ & $2,78 \pm 0,15$ \\
\hline$T x / T c$ & $1,26 \pm 0,11^{*}$ & $1,97 \pm 0,07$ \\
\hline ЦІК, одиниць оптичної щільності & $6,48 \pm 0,51 *$ & $3,42 \pm 0,23$ \\
\hline $\operatorname{Ig} A$, г/л & $2,45 \pm 0,17$ & $2,25 \pm 0,26$ \\
\hline $\operatorname{Ig} M$, г/л & $1,71 \pm 0,10$ & $1,53 \pm 0,11$ \\
\hline $\operatorname{IgG,~Г/л~}$ & $12,72 \pm 0,81$ & $12,72 \pm 0,42$ \\
\hline
\end{tabular}

Примітка:* $-p<0,05$ порівняно з контролем.

Для визначення функціональної активності $T$-клітин визначали кількість лімфоцитів із рецепторами до IL-2 (CD25+), FAS/APO-1(CD95+), HLA-DR+ (табл. 2). Спостерігали достовірне зростання кількості CD95+ лімфоцитів: у 34,6 \% хворих - третьо- 
го ступеня та у 30,8 \% - другого ступеня. У 26,9 \% хворих достовірно підвищена кількість CD25+ лімфоцитів. Також спостерігали тенденцію до підвищення кількості HLA$\mathrm{DR}+$ лімфоцитів. HLA-DR-молекули є активаційними маркерами лімфоцитів, які беруть участь у презентації антигенів; підвищення їх експресії на поверхні лімфоцитів відображає розвиток імунних реакцій у відповідь на антигенну стимуляцію.

Активовані рецептори на лімфоцитах периферичної крові досліджених хворих

Таблиия 2

\begin{tabular}{|l|c|c|}
\hline \multicolumn{1}{|c|}{ Показник } & Хворі $(n=45)$ & Контроль $(n=41)$ \\
\hline $\mathrm{CD} 25+, \%$ & $25,33 \pm 1,38^{*}$ & $20,37 \pm 0,89$ \\
\hline $\mathrm{CD} 25+, 10^{9} /$ л & $0,35 \pm 0,03$ & $0,34 \pm 0,02$ \\
\hline $\mathrm{CD} 95+, \%$ & $26,37 \pm 1,06^{*}$ & $17,24 \pm 0,57$ \\
\hline $\mathrm{CD} 95+, 10^{9} /$ л & $0,35 \pm 0,03$ & $0,32 \pm 0,02$ \\
\hline HLA-DR+, \% & $22,78 \pm 1,39$ & $21,49 \pm 0,59$ \\
\hline HLA-DR+, $10^{9} /$ л & $0,31 \pm 0,03$ & $0,33 \pm 0,02$ \\
\hline
\end{tabular}

Примітка: * $-p<0,05$ порівняно з контролем.

Отримані дані дозволили встановити рейтинговий алгоритм імунних порушень хворих на неспецифічний виразковий коліт: $\mathrm{Tx}_{2},{ }^{-} \mathrm{T}_{2},{ }^{-} \mathrm{Tx} / \mathrm{Tc}_{2},{ }^{-} \mathrm{CD} 95_{3},{ }^{+} \mathrm{B}_{3}{ }^{+} \mathrm{T} / \mathrm{B}_{2},{ }^{-} \mathrm{CD} 25_{3}{ }^{+}$ ЦІК $_{3}{ }^{+}$. У таблиці 3 наведено дані про вміст досліджених прозапальних цитокінів у сироватці крові обстежених хворих. Встановлено збільшення рівня ІЛ-8, ІФН- $\gamma$, ФНП- $\alpha$. Найбільш вагомі відхилення притаманні ІЛ-8, рівень якого збільшений майже у 5 разів, та ФНП- $\alpha$.

Таблиия 3

Рівень цитокінів у сироватці крові хворих на неспецифічний виразковий коліт

\begin{tabular}{|l|c|c|}
\hline \multicolumn{1}{|c|}{ Вміст цитокінів, пг/мл } & Хворі $(n=21)$ & Контроль $(n=10)$ \\
\hline $\mathrm{IЛ-} 8$ & $132,86 \pm 25,48^{*}$ & $26,02 \pm 2,62$ \\
\hline$\Phi Н П-\alpha$ & $119,97 \pm 30,56^{*}$ & $2,21 \pm 0,81$ \\
\hline $\mathrm{I} Ф \mathrm{H}-\alpha$ & $33,49 \pm 4,72$ & $43,51 \pm 1,82$ \\
\hline $\mathrm{I} Ф \mathrm{H}-\gamma$ & $67,48 \pm 12,16^{*}$ & $21,34 \pm 2,06$ \\
\hline
\end{tabular}

Примітка: ${ }^{*}-p<0,05$ порівняно з контролем.

Крім того, встановили кореляційний зв'язок між рівнем ІФН- $\alpha$ та ІФН- $\gamma(r=0,693$, $p<0,001)$. Відомо, що ФНП- $\alpha \epsilon$ найсильнішим індуктором синтезу ІЛ-8. У нашому дослідженні рівень ІЛ-8 корелює з рівнем ФНП- $\alpha(r=0,602, p<0,001)$. ІЛ-8 виконує імунорегуляторну роль у патогенезі запального процесу, сприяє хемотаксису нейтрофілів у зону запалення, активує нейтрофіли, може призводити до пошкодження тканин. ІФН$\gamma$ - головний фактор імунного запалення, він стимулює синтез супероксидрадикалів та окису азоту, підвищений рівень ІФН- $\gamma$ вказує на активацію імунної системи.

\section{Висновки}

У хворих на неспецифічний виразковий коліт установлено клітинний дисбаланс у $T$-ланці імунітету за рахунок зниження рівня $T$-хелперів, що призводить до імунорегуляційних розладів. Установлено активацію гуморального імунітету в обстежених хворих. Крім цього, у хворих на неспецифічний виразковий коліт спостерігали достовірне зростання кількості лімфоцитів із фенотипом CD95+, що вказує на наявність компенсаторного механізму видалення антигенспецифічного клону ефекторних клітин. Достовірне підвищення рівня ІЛ-8, ІФН- $\gamma$, ФНП- $\alpha$ відображає активацію імунних запальних механізмів у обстежених хворих. 


\section{Бібліографічні посилання}

1. Адлер Г. Болезнь Крона и язвенный колит. - М. : Геотармед, 2001. - 527 с.

2. Белоусова Е. А. Язвенный колит и болезнь Крона. - М. : Триада, 2002. - 127 с.

3. Дорофєєв А. Е. Клініко-патогенетична характеристика неспецифічного виразкового коліту 3 позакишковими ураженнями та оптимізація його терапії : Автореф. дис. ... д-ра мед. наук / Дніпропетровська медична академія. - Д., 2004. - 40 с.

4. Змушко Е. И. Клиническая иммунология: Руководство для врачей / Е. И. Змушко, Е. С. Белозеров, Ю. А. Митин. - СПб. : Питер, 2001. - 576 с.

5. Павленко В. В. Продукция интерлейкина-1 $\beta$ мононуклеарами периферической крови больных язвенным колитом / В. В. Павленко, А. А. Ягода // Российский журн. гастроэнтерол., гепатол., колопроктол. - 2001. - № 5. - С. 37-40.

6. Пасиешвили Л. М. Состояние и роль цитокинового звена иммунитета в становлении и прогрессировании заболеваний пищеварительного канала / Л. М. Пасиешвили, М. В. Моргулис // Сучасна гастроентерологія. - 2004. - № 3. - С. 8-11.

7. Роль цитокинов в патогенезе язвенного колита / И. В. Маев, С. С. Григорян, М. Г. Гаджиева, Н. И. Овчинникова // Клиническая медицина. - 2002. - № 1. - С. 15-19.

8. Сапроненков П. М. Иммунология желудочно-кишечного тракта. - М. : Наука, 1987. - 159 с.

9. 1000 формул клинической иммунологии / А. М. Земсков, В. М. Земсков, Ю. В. Сергеев и др. М. : Медицина для всех, 2003. - С. 47-51.

10. Шептулин А. А. Неспецифический язвенный колит: современные представления о патогенезе, диагностике и лечении // Клин. перспективы гастроэнтерол., гепатол. - 2001. - № 5. - С. 8-15.

11. Herrlinger K. Standard therapy for ulcerative colitis-evidece-based and consensus-based recommendations / K. Herrlinger, K. Fellermann, E. F. Stange // Internist. - 2002. - Vol. 43, N 11. P. 1367-1375.

12. Krishnan A. Inflammatory bowel diseases and environmental influences / A. Krishnan, J. R. Korzenik // Gastroenterology Clinics of North America. - 2002. - Vol. 31, N 1. - P. 21-39.

13. Local and systemic liberation of proinflammatory cytokines in ulcerative colitis / M. Gotteland, M. Lopez, C. Munoz et al. // Dig. Dis. Sci. - 1999. - Vol. 44, N 4. - P. 830-835.

14. Lorens-Meyer H. Inflammatory bowel disease. Laboratory Diagnostics. - 2001. - 40 p.

15. Simple method of circulating immune complex cloteetion in human polyethilen glicol precipitation / V. Haskova, K. L. Xaslik, F. Rina et al. // J. Immunol. - 1978. - Vol. 154, N 4. - P. 399-406.

Надійшла до редколегії 26.01.2009 